\title{
PEMANFAATAN DIGITAL MARKETING DALAM E-COMMERCE DI MASA PANDEMI COVID-19 PADA MAJELIS TALIM HIDAYATUL MUBTADIIN
}

\author{
Kartika Mariskhana1), Nining Suharyanti2), Murniyati ${ }^{3)}$, Endang Suparni ${ }^{4)}$, \\ Achmad Syahlani ${ }^{5}$, Desy Tri Anggarini $\left.{ }^{6}\right)$ \\ ${ }^{122) 334) 556)}$ Sistem Informasi, Fakultas Teknik dan Informatika \\ Universitas Bina Sarana Informatika \\ Jl. Kramat Raya No.98, Kwitang, Kec. Senen, Kota Jakarta Pusat, Jakarta \\ kartika.kma@bsi.ac.id¹),nining.nni@bsi.ac.id²), murni.mni@bsi.ac.id3); endang.esp@bsi.ac.id²), \\ achmad.acy@bsi.ac.id 5); desy.dra@bsi.ac.id6)
}

\begin{abstract}
The increase in positive cases of the Covid-19 corona virus in Jakarta has again increased sharply and since the PSBB transition from June 4 to July 2 the number of new cases found was 6,748 cases. In addition, the DKI Jakarta Provincial Government always pays attention to the percentage that appears, as an effort to anticipate and control the development of Covid-19. For this reason, digital marketing media is an effective medium in the Covid 19 era. Digital marketing training in E-commerce at the Taklim Hidayatul Mubtadiin Council is expected to be a useful contribution to improving quality and ability in digital marketing marketing more effectively. The training is conducted using direct methods of delivering theory and practice. At the end of the training, participants expressed satisfaction with the figure 95\% of the results of the questionnaire distributed to them. Most of them stated that the training materials were suitable for their needs, because they could support their work. Furthermore, they also said that the material provided was complete and easy to understand, many said that, namely $95.67 \%$.
\end{abstract}

Keywords: Digital Marketing, Training.

\begin{abstract}
Abstrak
Meningkatnya kasus positif virus corona Covid-19 di Jakarta kembali meningkat tajam dan sejak PSBB transisi 4 Juni sampai dengan 2 Juli jumlah kasus baru yang ditemukan 6.748 kasus. Selain itu Pemprov DKI Jakarta pun selalu memperhatikan angka presentase yang muncul, sebagai upaya antisipasi dan mengendalikan perkembangan dari Covid-19. Untuk itu media digital marketing adalah media yang efektif dalam era covid 19. Pelatihan Digital marketing dalam E-commerce pada Majelis Taklim Hidayatul Mubtadiin ini diharapkan dapat menjadi kontribusi yang bermanfaat untuk peningkatan kualitas dan kemampuan dalam pemasaran digital marketing lebih efektif. Pelatihan dilakukan dengan metode penyampaian teori dan praktek secara langsung. Pada akhir pelatihan, peserta menyatakan puas dengan angka $95 \%$ dari hasil kuesioner yang disebarkan kepada mereka. Hampir rata-rata menyatakan bahwa materi pelatihan sesuai dengan kebutuhan mereka, karena dapat menunjang pekerjaan. Selanjutnya mereka juga mengatakan bahwa materi yang diberikan lengkap dan mudah dipahami, banyak yang menyatakan demikian, yakni sebesar 95, 67\%.
\end{abstract}

Kata kunci: Pelatihan, Digital Marketing.

\section{PENDAHULUAN}

Pada awal Januari tahun 2020, Cina melaku kan identifikasi pneumonia yang tidak diketahui etiologinya sebagai corona virus (corona virus disease, COVID-19) [1], sedangkan di Indonesia Pada tanggal 2 Maret 2020, untuk pertama kalinya pemerintah mengumumkan dua kasus pasien positif Covid-19 di Indonesia [2]. Namun, Pakar Epidemiologi Universitas Indonesia (UI) Pandu Riono menyebutkan virus corona jenis SARS-CoV-2 sebagai penyebab Covid-19 itu sudah masuk ke Indonesia [3] sejak awal Januari. "Sejak awal Januari kemungkinan besar virus (SARS-CoV-2) itu 
sudah masuk ke Indonesia," kata Pandu dalam diskusi daring bertajuk "Mobilitas Penduduk dan Covid-19: Implikasi Sosial, Ekonomi dan Politik" pada Senin (4/5/2020). [3] Masuknya virus tersebut sangat mungkin terjadi melalui pintupintu gerbang di beberapa wilayah Indonesia. Sejak Januari saat virus corona jenis baru ini diumumkan dapat menular antar manusia, dan sudah menjajah di berbagai negara lain selain Wuhan di China.[4]

Kasus positif 19 di Jakarta kembali meningkat tajam. Kemudian pada 2-8 Juli 2020 dari 34.007 orang yang di tes positivity ratenya $4,8 \%$. Dia mengingatkan jangan menganggap enteng dan merasa sudah terbebas dari Covid-19. Anies mengatakan sejak PSBB transisi 4 Juni sampai dengan 2 Juli jumlah kasus baru yang ditemukan 6.748 kasus [5]. Selain itu Pemprov DKI Jakarta pun selalu memperhatikan angka presentase yang muncul, sebagai upaya anti- sipasi dan mengen dalikan perkembangan dari Covid-19. Aturan terkait Work From Home (WFH) untuk sektor pemerintah maupun sektor swasta, terjadi perlambatan kegiatan usaha di akhir bulan Maret 2020 yang berpotensi menurunkan penyerahan dalam negeri yang kemudian akan menekan penerimaan Pajak Pertambahan Nilai Dalam Negeri (PPN DN) di bulan April 2020. [6]

Saat ini Pemasaran melalui digital marketing agar jangkauannya luas dan biaya lebih murah. Keberadaan media sosial menjadi sarana bagi konsumen yang dapat digunakan untuk menyebar kan informasi baik berupa teks, gambar, audio, dan video dengan banyak pihak [7] baik antar perusahaan Digital marketing merupakan kegiatan pemasaran termasuk branding yang menggunakan berbagi media berbasis website. Sebagai contoh adalah blog, website, e-mail, adwords, dan berbagai macam jaringan sosial media. [8].

Pemasaran melalui digital marketing memudahakan promosi penjualan, dengan menggunakan media sosial agar jangkauannya luas dan biaya lebih murah. Keberadaan media sosial menjadi sarana bagi konsumen yang dapat digunakan untuk menyebarkan informasi baik berupa teks, gambar, audio, dan video dengan banyak pihak baik antar perusahaan kepada konsumen atau konsumen pada perusahan[9]

Media sosial merupakan media pilihan yang digemari oleh masyarakat. Hal ini didukung dengan keberadaan telepon seluler yang menyediakan fitur-fitur yang terhubung dengan Intrenet, sehingga siapapun dapat mengakses media sosialnya [7] dengan cepat, mudah, dimana pun berada. Dengan teknologi komunikasi yang semakin berkembang membuat keterbukaan informasi serta pola penyebaran informasi juga ikut berubah. Digital marketing sebagai media promosi bertujuan untuk menyampaikan atau menyebarluaskan atau memasarkan tentang suatu produk sehingga dapat memengaruhi konsumen untuk membelinya. [7] [10]

Promosi merupa kan salah satu dari bauran pemasaran (marketing mix) yang sangat penting bagi pelaku bisnis untuk memasarkan produknya baik jasa maupun produk. Promosi juga merupakan salah satu cara untuk meningkatkan penjualan, karena promosi dapat menarik perhatian konsumen untuk melakukan keputusan pembelian suatu produk. Promosi merupakan suatu bentuk komunikasi pemasaran yang merupakan aktivitas pemasaran yang berusaha menyebarkan informasi, mem- pengaruhi/membujuk, dan/atau meningkatkan [11] pasar sasaran atas perusahaan dan produknya agar bersedia menerima, membeli, dan loyal pada produk yang ditawarkan perusahaan yang bersangkutan.[12]

Pesatnya perkembangan teknologi, dunia digital dan internet tentu juga berimbas pada dunia pemasaran. Tren pemasaran di dunia beralih dari yang semula konvensional (offline) menjadi digital (online). Strategi digital marketing ini lebih prospektif karena memungkinkan para calon pelanggan potensial untuk memperoleh segala macam informasi mengenai produk dan bertransaksi [13] melalui internet. Dalam dunia maya kini tak lagi hanya mampu menghubungkan orang dengan perangkat, namun juga orang dengan orang lain di seluruh penjuru dunia. Digital marketing yang biasanya terdiri dari pemasaran interaktif dan terpadu memudahkan interaksi antara produsen, perantara pasar, dan calon konsumen.

Platform yang sering digunakan dalam digital marketing adalah media sosial atau jejaring sosial. Saat ini medsos sudah menjadi kebutuhan manusia saat ini. Tak sekadar berbagi informasi tapi juga untuk hiburan bahkan menjadi lahan mata pencaharian. Penelitian We Are Social 2020 menemukan rata-rata waktu yang dihabiskan pengguna Indonesia usia 16-64 dalam mengakses media sosial mencapai 3 jam 26 menit sehari. Penetrasi pengguna medsos pun terus meningkat termasuk Indonesia, yang kini 59 persen dari 272,1 juta total penduduknya adalah pengguna media sosial. Angka ini meningkat lebih dari 8,1 persen atau setara dengan lebih dari 12 juta pengguna dari April 2019.[14]

Tahun ini Indonesia mempunyai 160 juta pengguna aktif media sosial yang 99 persen penggunanya mengakses media sosial melalui ponsel. Kian digandrungi banyak orang, media sosial menjadi tempat yang nyaman untuk berkomunikasi dan bertukar informasi. Media sosial sering digunakan untuk mengekspresikan 
diri dengan suatu karya berupa tulisan, foto, dan video. Hal tersebut tercermin dalam hasil penelitian Sensor Tower, penyedia riset pasar intelligence terpercaya untuk ekonomi aplikasi global, di kuartal kedua 2020 yang merilis daftar media sosial terpopuler di dunia saat ini sebagai berikut TikTok merupakan aplikasi video singkat yang dilengkapi dengan berbagai filter, musik, dan fitur lainnya. Selain bisa menikmati video-video, tahun 2020, TikTok telah diunduh lebih dari 300 juta pengguna Facebook (kuartal kedua 2020 mencapai lebih dari 2,7 miliar). Instagram 2020 ini merupakan platform visual terbesar saat ini. Snapchat aplikasi pesan mobile yang unik dimana pada tahun 2020 mencapai lebih dari 300 juta per bulannya. Likee Aplikasi membuat video kreatif dan telah memiliki lebih dari 150 juta total pengguna di seluruh dunia.

Dengan memanfaatkan teknologi informasi, maka dapat memberikan potensi yang besar dalam meningkatkan pendapatan masyarakat, dalam hal ini anggota Majelis Taklim Hidayatul Mubtadiin, dapat memanfaatkan e-commerce dan market place yang dapat memberikan peluang yang besar untuk bisa meningkatkan penjualan produk mereka melalui media digital. Mereka cukup bermodalkan smartphone dan paket internet dalam memasarkan produknya dengan mudah. Sebagai contoh, dengan memanfaatkan media sosial yang sedang hits saat ini seperti aplikasi Instagram, Facebook, ataupun membuat akun ecommerce di market place yang ada di Indonesia.

Dewasa ini sudah saatnya pelaku usaha mempersiapkan diri untuk memasuki era baru dalam dunia pemasaran. Sebab selama ini, kelemahan menentukan strategi pemasaran yang efektif dan efisien menjadi persoalan bagi hampir seluruh pelaku usaha di tanah air [15]. Media digital kini menjadi media penting yang digunakan di setiap kalangan masyarakat. Media digital tumbuh pesat seiring dengan bertambahnya pengguna internet di kawasan Asia Tenggara. Media digital pun bahkan sudah menjadi gaya hidup modern, di samping itu penggunaan media digital telah banyak membantu setiap orang dalam melakukan rutinitas. Individu, organisasi, bahkan pemerintahan juga tidak pernah terlepas dari aktifitas menggunakan media digital. Contoh media digital yang sering digunakan saat ini, yaitu : Facebook, Twitter, Instagram, dan YouTube. Masing-masing media digital tersebut mempunyai fungsi yang sama, yaitu untuk berkomunikasi. Banyaknya kemudahan dan fungsi dari penggunaan media digital, mendorong masyarakat atau pengusaha untuk memaanfaatkan media digital tersebut pada setiap kegiatannya. Fungsi lain dari penggunaan media digital meliputi: branding, sharing, promosi, maupun marketing. Perkembangan teknologi informasi dan internet juga berpengaruh besar terhadap perkembangan di bidang promosi produk. Hal tersebut tentunya sangat menguntungkan bagi dunia promosi produk karena kemudian terjadi peningkatan efektivitas jika dibandingkan dengan media konvensional. Aspek utama yang mempengaruhi peningkatan efektivitas promosi produk melalui internet adalah media yang inter aktif, bersifat fleksibel dengan pengertian adanya pertukaran pesan dua arah dan media yang responsif

Secara umum remaja Majelis Taklim Hidayatul Mubtadiin mempunyai banyak hambatan termasuk permasalahan dalam mengembangkan usahanya adalah pemahaman mengenai memasarkan produk. Apalagi saat sekarang ini pemasaran dengan menggunakan digital marketing dirasakan masih terbatas.

Perkembangan teknologi membawa dampak dalam berbagai aspek kehidupan manusia. Perekonomian pun tidak luput dari sentuhan teknologi. Teknologi menawarkan berbagai kemudahan dalam perekonomian yang tentunya sangat menunjang sistem perekonomian yang ada. Salah satunya adalah peranan teknologi dalam perdagangan yang saat ini dikenal dengan ECommerce. E-Commerce atau perdagangan elektronik atau e-dagang adalah penyebaran, pembelian, penjualan, pemasaran barang dan jasa melalui sistem elektronik seperti internet atau televisi, www, atau jaringan komputer lainnya. ECommerce dapat melibatkan transfer dana elektronik, pertukaran data elektronik, sistem manajemen inventori otomatis, dan sistem pengumpulan data otomatis. Industri teknologi informasi melihat kegiatan e-dagang ini sebagai aplikasi dan penerapan dari elektronik bisnis (ebisnis) yang berkaitan dengan transaksi komersial seperti: transfer dana secara elektronik, SCM (Supply chain management), e-pemasaran, atau pemasaran online, pemrosesan transaksi online, pertukaran data elektronik, dan lain-lain

Dalam keseharian remaja Majelis Taklim Hidayatul Mubtadiin yang terdiri dari usia 12-17 tahun, mereka sudah memiliki media sosial seperti Facebook, instagram, twitter dan beberapa media sosial dan chating, namun pemanfaatan dalam pemasaran belum efektif digunakan. Jadi dalam kegiatan ini kita mengenalkan media digital marketing sebagai media pemasaran yang efektif pada pandemic Covid-19. Permasalahan yang dihadapi remaja Majelis Taklim Hidayatul Mubtadiin, kurang menguasai dalam segi penggunaan ecommerce dalam pemanfaat pemasaran, juga dalam strategi digital marketing, mereka masih kurang, sehingga perlu pemahaman 
pemasara, pemanfaat produk, membuat suatu merk yang menarik.

Kesadaran remaja Majelis Taklim Hidayatul Mubtadiin adalah dalam memaksimalkan pemanfaatan teknologi belum produktif di era digital sekarang ini, sedangkan mayoritas para remaja mempunyai smart phone. Padahal pemanfaatan akses internet ini sangat memungkinkan seseorang berinteraksi bahkan bertransaksi secara ekonomi di dunia teknologi online (internet), sehingga hal tersebut bisa menjadi lahan baru wirausahawan muda dalam mempromosikan serta memasarkan produknya.

Sehingga dapat disimpulkan permasalahan yang ada dan alasan pengabdian masyarakat ini

1. Sosialisasi ini dapat membantu Majelis Taklim Hidayatul Mubtadiin dalam pemanfaatan teknologi internet di bidang jual beli secara online.

2. Belum produktifnya para Majelis Taklim Hidayatul Mubtadiin dalam menggunakan internet atau media online.

3. Belum memahami cara memasarkan produk melalui media internet, Belum mengetahui dan memahami cara mengoperasikan akun (Account) transaksi online.

4. Sehingga program ini dapat memproduktif kan penggunaan internet atau media online dari segi transaksi ekonomi secara online, Mitra dalam program ini memahami cara memasrkan produk melalui media internet. Mitra memahami cara mengoperasikan akun transaksi online.

Pelatihan kegiatan pengabdian masyarakat ini memiliki manfaat antara lain :

a. Bagi Pelaksana (Universitas Bina Sarana Informatika )

1) Sebagai sarana untuk membantu perekonomian di era covid 19.

2) Meningkatkan partisipasi dalam masy umum.

3) Sebagai sarana untuk memberikan pengetahuan sebagai civitas akademik dalam program pengabdian pada masyarakat sebagai bagian integral dari Tri Darma perguruan tinggi.

b. Bagi Peserta

1) Sebagai salah satu sarana untuk mendapatkan pengetahuan bidang digital marketing

2) Sebagai bekal keterampilan untuk menjadi entrepreneur muda

c. Bagi Pemerintah Daerah

1) Membantu program pemerintah dalam meningkatkan kualitas sumber daya manusia dan entreprenurship
2) Membantu program pemerintah mempercepat laju pembangunan di era covid -19

\section{METODE PENGABDIAN MASYARAKAT}

Tahapan kajian yang digunakan untuk menyelesaikan permasalahan kegiatan pengabdian masyarakat ini, antara lain :

a. Analisa kebutuhan pelatihan

b. Pembuatan proposal

c. Pembuatan modul dan slide presentasi

d. Persiapan pelatihan

e. Pelaksanaan pelatihan

f. Penyusunan laporan

Pelaksanaan kegiatan pengabdian masyarakat diikuti oleh Anggota Remaja Majelis Taklim Hidayatul Mubtadiin secara online melalui video confrence Zoom dikarenakan adanya covid-19 dan mengikuti anjuran pemerintah PSBB. Adapun kegiatan Pengabdian Masyarakat (PM) tersebut berupa Pemanfaatan Digital Marketing dalam ECommerce di Masa Pandemi Covid-19.

Pemberian arahan oleh tutor mengenai pemahaman dari beberapa ragam akses yang dapat ditawarkan seperti Website, Media sosial (facebook, shoppee, Instagram) dengan memberi materi tersebut.

Metode kegiatan pelatihan ini dilakukan berdasarkan pendekatan proses penjelasan teori disertai praktikum langsung melalui zoom meeting Metode pelatihan untuk menyampaikan teori, meliputi ceramah, tanya jawab dan diskusi, sedangkan praktikum terdiri dari metode simulasi, Secara rinci metode yang dilakukan adalah sebagai berikut:

a. Menjelaskan cara penggunaan tools dasar dan fitur-fitur penggunaan Website, Media sosial (facebook, shoppee, Instagram)

b. Penjelasan disertai dengan praktek langsung.

c. Selama kegiatan pelatihan peserta diberikan luas kesempatan untuk bertanya jika ada materi yang kurang dipahami.

\section{HASIL DAN PEMBAHASAN}

\section{Materi pelatihan}

Cakupan materi yang disampaikan adalah:

1. Pengenalan awal tentang fitur-fitur penggunaan Website, Media sosial (facebook, shoppee, Instagram).kemudian mengenai ecomerce melalui internet.

2. Membuat Website/ Blog Khusus untuk Bisnis

3. Pemasaran Bisnis dengan Email Marketing

4. Pemasaran Melalui Media Sosial 


\section{Pemasaran Melalui Jaringan Periklanan}

6. Pemasaran Melalui Konten Marketing

\section{Instrumen Pelaksanaan}

Dalam pelaksanaan program pelatihan ini di butuhkan instruktur, modul pelatihan, sarana komputer, LCD (Proyektor). Dalam pelaksanaan nya, keterkaitan dari komponen instrumen tersebut menjadi satu kesatuan yang mengikat karena metode pelatihan dilakukan dalam suatu ruangan sebagai tempat praktek. Sehingga dalam pelaksanaan pelatihan, keberadaan instruktur yakni memandu pemberian teori dan praktek pelatihan, diharapkan peserta mampu memahami modul dan dapat mengikuti arahan dari instruktur. Selanjutnya, keberadaan komputer digunakan sebagai media simulasi dan praktek.

\section{Pelaksanaan Pelatihan}

Pelatihan dilakukan di Majelis Taklim Hidayatul Mubtadiin, Tangerang dengan pengenalan awal tentang fitur-fitur penggunaan Website, Media sosial (facebook, shoppee, Instagram), kemudian mengenai e-comerce melalui internet. Peserta juga diajarkan membuat Website/ Blog Khusus untuk Bisnis.

Setiap peserta mendapat kesempatan untuk menggunakan perangkat komputer dan juga dapat menggunakan aplikasi melalui hp, seperti Facebook, Instagram dan Shopee dari cara membuat account seperti dalam instagram daftar untuk akun Instagram dan pilih nama pengguna yang secara jelas mewakili bisnis Anda, seperti nama bisnis Anda, kemudian menambahkan foto profil, biografi, dan tautan ke situs web Anda dan mengubah kembali ke profil bisnis. Profil bisnis Anda harus memiliki Halaman Facebook untuk beralih ke profil bisnis..

Masing-masing instruktur secara bergantian sesuai materinya, memandu pemberian teori pelatihan dan memberikan contoh ke dalam praktek seperti pemasaran bisnis dengan email marketing

Pemberian teori pemasaran melalui media sosial dilakukan bersamaan dengan pemberian latihan praktek sehingga para peserta dapat langsung mempraktikkannya. Hal ini dapat dilihat pada gambar Berikut gambar 1 dan gambar 2 Kegiatan peserta PM di Lokasi Majelis Talim Hidayatul Mubtadiin

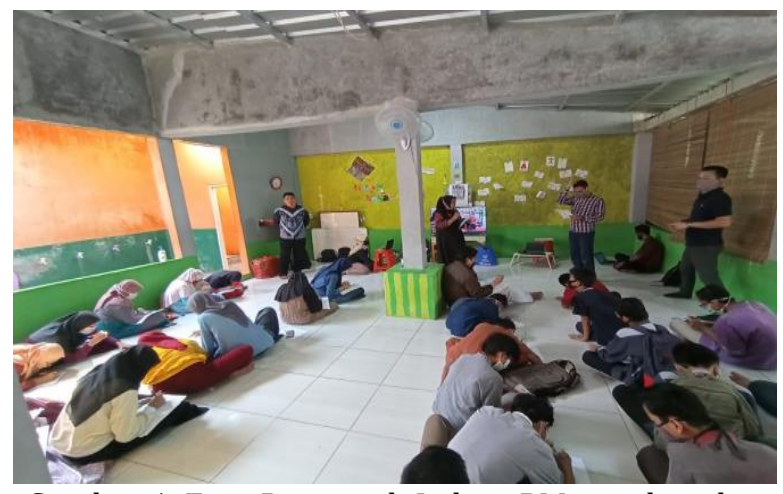

Gambar 1. Foto Peserta di Lokasi PM majelis talim hidayatul Mubtadiin

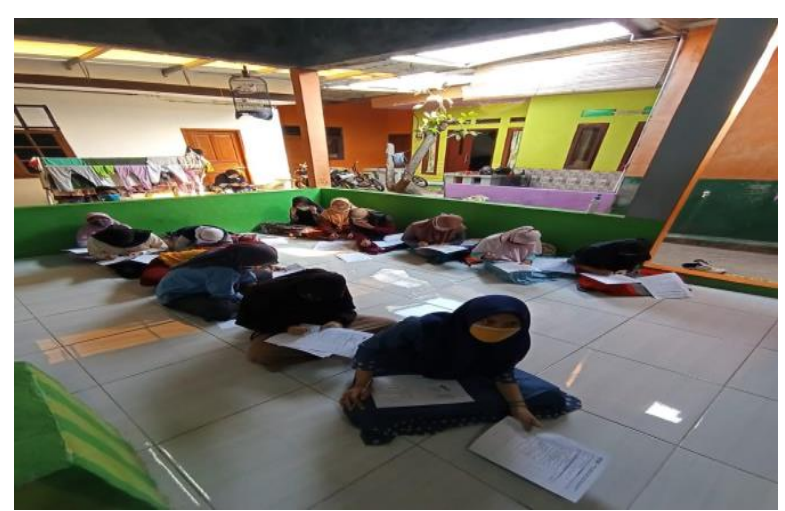

Gambar 2. Foto Peserta Pengabdian Masyarakat

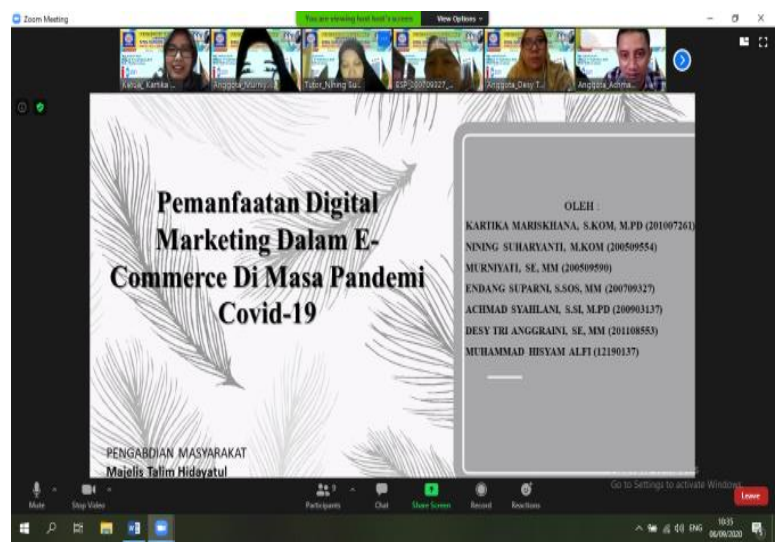

Gambar 3. Pemberian Materi PM Mengenai

Pemanfaatan Digital Marketing melalui Zoom

Class.

Gambar 3 dan Gambar 4 menjelaskan mengenai peran dari era digital dalam memanfaatkan marketing dgital di masa pandemi sangat berguna, mengingat orang saat ini hanya bekerja dan belajar dari rumah, oleh karena itu mereka memanfaakan media internet untuk melakukan berbagai kegiatan maupun dalam bertransaksi dalam berbelanja secara online. 


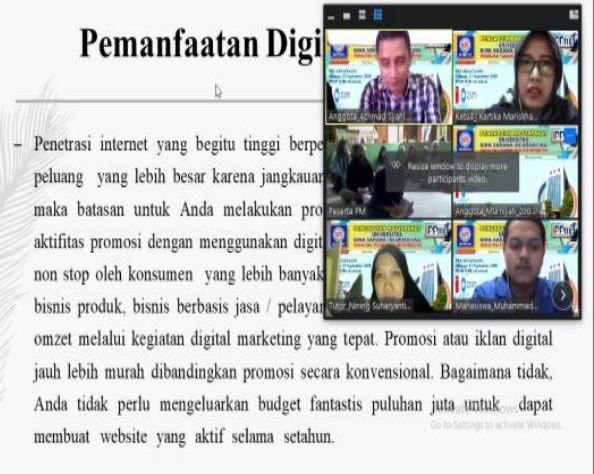

Gambar 4. Materi Pemanfaatan Digital

Selama pelatihan, para peserta sangat antusias mengikuti jalannya pelatihan karena dukungan sarana dan prasarana memadai yang diberikan, sehingga mereka dapat memperoleh kesempatan mempraktikkan langsung materi yang terdapat pada modul. Dengan begitu, mereka merasa lebih bisa mengeksplorasi dengan baik dan lebih mampu memahami secara terperinci materi yang berikan, seperti pemasaran melalui media sosial, pemasaran melalui jaringan periklanan, pemasaran melalui konten marketing.

Dilihat dari aktivitas peserta pelatihan, maka terlihat respon para peserta sangat tinggi. Banyak diantara mereka yang bertanya tentang bagaimana pemasaran melalui media sosial, pemasaran melalui jaringan periklanan, pemasaran melalui konten marketing dan kemudian terlibat dalam diskusi, dan kemudian menindaklanjutinya dengan praktek materi yang mereka pertanyakan.

Anggota majelis taklim mendapatkan ilmu baru serta tips dan trik untuk menguasai pemasaran melalui digital marketing, sehingga dapat bekerja secara cepat dan efektif. Sedangkan mengenai kendala pada saat pelatihan, yaitu masih adanya peserta yang tidak menguasai internet dan komputer. Oleh karena itu melalui pelatihan ini dapat menambah wawasan ilmu pengetahuan bagi para peserta di bidang teknologi informasi khususnya pemasaran melalui media sosial, pemasaran melalui jaringan periklanan, pemasaran melalui konten marketing dan e-commerce. yang dapat menambah keterampilan yang dapat diterapkan dan dimanfaatkan langsung oleh para peserta dalam meningkatkan kualitas diri.

Kegiatan pelatihan digital marketing untuk para Remaja Majelis Taklim Hidayatul Mubtadiin yang dilaksana di majelis taklim Hidayatul Mubtadiin sejak pukul 9.30 sd 12.00 WIB. Pelaksanaan pelatihan ini mendapat tanggapan yang positif dari peserta kegiatan. Hal ini dapat diamati dari kesungguhan dan keingintahuan peserta dengan mengajukan beberapa pertanyaan dan usulan tentang kegiatan pelatihan selanjutnya guna meningkatkan kemampuan mereka di bidang teknologi terkini.

Selanjutnya untuk mengukur kepuasan peserta pelatihan juga terlihat dari hasil kuesioner yang disebarkan untuk mendapat respon a tas pelaksanaan pelatihan, dengan menggunakan instrumen berupa kuesioner.

Responden sebanyak 28 peserta. Berikut ini adalah daftar pertanyaan kuesioner

Pertanyaan dalam kuesioner :

P1 Personil/anggota yang terlibat dalam kegiatan pengabdian masyarakat memberikan pelayanan sesuai dengan kebutuhan peserta

P2 Tutor menyampaikan materi kegiatan dengan jelas dan mudah dimengerti oleh peserta

P3 Setiap keluhan/pertanyaan/permasalahan yang diajukan ditindaklanjuti dengan baik oleh tutor yang terlibat

P4 Materi yang disampaikan sesuai dengan kebutuhan peserta dalam menambah wawasan, pengetahuan, keterampilan dan keahlian peserta

P5 Peserta mendapatkan materi kegiatan berupa modul dan soal latihan

P6 Peralatan untuk menyampaikan materi memadai

P7 Kegiatan pengabdian masyarakat yang disampaikan bermanfaat untuk menambah wawasan, pengetahuan, keterampilan dan keahlian peserta

P8 Saya merasa puas dengan kegiatan pengabdian masyarakat yang diselenggarakan STMIK Nusa Mandiri

P9 Kegiatan pengabdian masyarakat yang diselenggarakan STMIK Nusa Mandiri sesuai dengan harapan saya

P10 Jika kegiatan ini diselenggarakan kembali, saya bersedia untuk berpartisipasi/terlibat

Dari 10 pertanyaan yang diberikan, 5 hasil respon jawaban teratas adalah :

1. Instruktur berpenampilan baik dan bersuara jelas dalam penyampaian materi $=92 \%$

2. Bahan ajar (modul/handout/file ppt) tersedia dengan baik $=94,5 \%$

3. Fasilitas (PC, LCD Projector, papan tulis, koneksi internet) tersedia dan bekerja dengan baik $=95,20 \%$

4. Materi pelatihan sesuai dengan kebutuhan Anda, sehingga mampu menunjang pekerjaan yang Anda lakukan $=98 \%$

5. Materi yang diberikan lengkap dan dapat dengan mudah dipahami $=95,7 \%$ 
Sehingga dapat ditarik kesimpulan bahwa peserta puas dengan pelatihan ini, dengan materi pelatihan sesuai dengan kebutuhan peserta, sehingga mampu menunjang pekerjaan. Peserta juga menyatakan bahwa materi yang diberikan lengkap dan dapat dengan mudah dipahami, hal ini dinyatakan sebesar 98,10\%. Pelatihan ini diharapkan dapat menjadi kontribusi yang bermanfaat untuk peningkatan kualitas dan kemampuan anggota majelis Taklim Hidayatul Mubtadiin di bidang komputer.

\section{KESIMPULAN}

Kesimpulan dari kegiatan pelatihan ini adalah peserta Pengurus remaja Majelis Talim Hidayatul Mubtadiin Tangerang. Dapat menguasai mengaplikasikan digital marketing melalui ecommerce. Kegiatan pelatihan ini juga membawa dampak baik dalam upaya peningkatan penetrasi kemajuan teknologi informasi. Hal ini nampak dari respon positif yang diberikan oleh mereka sepanjang mengikuti kegiatan pelatihan. Berdasarkan observasi dilapangan dapat terlihat bahwa pemahaman peserta terhadap materi sudah baik dan pesertamampu menerapkan materi dalam modul yang telah diberikan.

\section{SARAN}

Saran yang dapat diberikan untuk kegiatan Pengabdian Kepada Masyarakat ini, antara lain diharapkan pihak Universitas Bina Sarana Informatika agar dapat terus bekerja sama kedepannya dengan institusi atau organisasi, guna memberikan pelatihan-pelatihan yang berguna dan bermanfaat, hal itu sebagai bagian dari realisasi Tri Darma Perguruan Tinggi untuk bekerjasama dan menebarkan ilmu pengetahuan serta wawasan kampus Universitas Bina Sarana Informatika (UBSI) kepada masyarakat. Pelatihan seperti ini harus dilakukan secara lebih intensif, tidak cukup hanya sekali saja. Perlu adanya pelatihan ke tahapan berikutnya, agar ilmu yang diserap peserta lebih banyak dan sistematis serta terperinci. Selanjutnya disarankan pula untuk membuat jadwal pelatihan yang terencana dengan baik, mengingat lagi masa pandemi covid agar lebih hatihati dalam mennetukan jadwal sesuai dengan jadwal kegiatan peserta.

\section{UCAPAN TERIMA KASIH}

Terimakasih kepada semua pihak yang telah mendukung antara lain:

1. Pengurus remaja Majelis Talim Hidayatul Mubtadiin

2. Pihak LPPM Universitas Bina Sarana Informatika (UBSI) Jakarta yang memberikan kemudahan fasilitas dalam pelaksanaan kegiatan.

3. Fakultas Teknik dan Informatika Universitas Bina Sarana Informatika.

4. Dan pihak-pihak yang tidak dapat disebutkan satu- persatu

\section{DAFTAR REFERENSI}

[1] Satuan Kerja: Poltekkes Kemenkes Banjarmasin, "Laporan Upaya Pencegahan Dan Pengendalian Covid-19 Poltekkes Kemenkes Banjarmasin," Banjarmasin, 2020.

[2] M. Joan, "Perubahan Tata Ibadah Gereja di Masa Pandemi Covid-19," kompasiana.com, 2020. [Online]. Available: https://www.kompasiana.com/maria123/ 5fc33eb1d541df78cf240982/perubahantata-ibadah-gereja-dimasa-pandemi-covid19.

[3] E. Pranita, "Diumumkan Awal Maret, Ahli: Virus Corona Masuk Indonesia dari Januari," Kompas.com, Jakarta, p. Sains, 11May-2020.

[4] Kemenkes, "Pedoman Kesiapsiagaan Menghadapi Coronavirus Disease (COVID 19)," Kementrian Kesehat. Republik Indones., vol. Direktorat, no. revisi ke 3, 2020.

[5] Redaksi, "Corona Jakarta Naik, Ini Peta Sebaran Berdasarkan Kelurahan," CNBC Indonesia, Jakarta, p. Tech, 13-Jul-2020.

[6] Kemenkeu, "Pemerintah Waspada Dampak Pandemi Covid-19 Terhadap Ekonomi Indonesia (siaranpress) Jakarta," Kementrian Keuang., no. April 2020, 2020.

[7] F. Oktaviani and D. Rustandi, "Implementasi Digital Marketing dalam Membangun Brand Awareness," PRofesi Humas, vol. 3, no. 1, pp. 1-20, 2018.

[8] 2009. Sanjaya, Ridwan dan Josua Tarigan, Creative Digital Marketing. Jakarta: PT Elex Media Komputindo. Jakarta., 2009.

[9] L. K. (2012). Kotler, P. \& Kevin, Manajemen pemasaran, 12th ed. Jakarta.

[10] M. E. Malik, "Implementasi Digital Marketing dalam Membangun Brand Awareness (Femi Oktaviani dan Diki Rustandi) loyalty in assessing purchase intentions of customer.," Int. J. Bus. Soc. Sci. Vol.04 No. 05., vol. Volume 4, no. 2018, pp. 1-29, 2013. 
[11] E. Tambunan, "Pengaruh Promosi Dan Kualitas Produk Terhadap Minat Beli Mahasiswa Farmasi Pada Kosmetik Wardah Di Universitas Sari Mutiara Indonesia Medan," J. Ilmiah"INTEGRITAS, vol. 5, no. 1, pp. 1-26, 2019.

[12] Selang, "Bauran Pemasaran (Marketing Mix) Pengaruhnya Terhadap Loyalitas Konsumen Pada Fresh Mart Bahu Mall Manado.," J. EMBA J. Ris. Ekon. Manajemen, Bisnis dan Akunt., vol. Nomor 3. V, p. 73, 2013.

[13] B. S. Pambudi and S. Suyono, "Digital Marketing As An Integrated Marketing
Communication Strategy In Badan Usaha Milik Desa (BUMdesa) In East Java," Competence J. Manag. Stud., vol. 13, no. 2, pp. 121-151, 2019.

[14] S. Kemp, "http://wearesocial.com/: http://wearesocial.com/blog/2017/0

2/digital-southeast-asia-2017 Khan, F., \& Siddiqui, K.," 2013.

[15] P. W. Widyaningrum and W. Bharata, "Workshop Internet dan Digital Marketing untuk Meningkatkan Daya Saing Pada Kelompok Pengusaha Muda Ponorogo," Adimas J. Pengabdi. Kpd. Masy., vol. 1, no. 1, pp. 1-7, 2017. 